\title{
AIDS drug trials to start amid controversy
}

\section{- United States follows Sweden in peptide tests - Others unable to reproduce laboratory data}

Washington

WITIIIN a few days of a decision by the US Food and Drug Administration to give the go-ahead for clinical trials of a new anti-AIDS drug, peptide $T$, controversy about the laboratory data on which the decision was based erupted at last week's International Conference on AIDS.

Speaking the day after Dr Candace Pert of the National Institute of Mental Health had added to her group's published data showing that peptide $T$ can inhibit the entry of AIDS viruses into cells, Dr William Haseltine of the Dana-Farber Cancer Center in Boston, claimed that six laboratories, including his own, cannot reproduce the published data. But at least one other laboratory has reproduced the data on the peptide, already being evaluated in Swedish AIDS patients.

The confirmation of Pert's original work, which was published at the end of last year, comes from scientists at Genetic Systems, the Seattle-based subsidiary of Bristol-Meyers; Pert cannot understand why others following her published

\section{Random survey for} AIDS infection

Washington

UNCERTAINTIES over just how many people in the US population are infected with the AIDS virus are to be resolved by a random survey, according to an announcement made by Health and Human Services Secretary, Dr Otis Bowen, after the close of the third international conference on AIDS (acquired immune deficiency syndrome).

Estimates of the rate of spread of the disease and the extent to which it has penetrated the heterosexual population vary widely and reliable data are urgently needed to establish a deadline. Dr Bowen is proposing that 45,000 citizens, selected to sample accurately the entire population, be asked to give blood samples that could be tested for presence of the AIDS virus. Details of how the survey would be carried out have not yet been released but it is certain that participation would be entirely voluntary and anonymity protected. Despite these safeguards the survey is bound to stimulate some controversy. To be effective, the number of people tested has to be large enough to include significant samples of the high-risk groups that include homosexuals and intravenous drug users. Members of such groups may be unwilling to participate. Alun Anderson protocol should be unable to get the same results. But Haseltine claims exactly that.

A letter from Haseltine and others who have been unable to reproduce any of Pert's data is due to be published by The Lancet. Pert is puzzled by the failure of Haseltine and others to discuss their data with her. Had they done so it would have been possible to ascertain whether the protocol had been followed precisely. Most important, says Pert, is that the concentrations of virus and peptide are as in her paper. That is also Genetic Systems' experience. Dr George Todaro says that in his experience the conditions described in the original paper in the Proceedings of the National Academy of Sciences of the U.S.A. have to be closely adhered to.

Pert is an outsider to AIDS research but has much experience of working on peptides and their receptors on cell membranes, particularly opioids and their receptors in the brain. Her interest in the infection of brain cells by the AIDS virus led to the synthesis and testing of peptide $\mathrm{T}$, the core amino-acid sequence of which closely resembles a segment of the envelope protein on the outside of AIDS viruses. It is that segment, she believes, that makes contact with the receptor for the virus on cell surfaces, leading to infection of the cell. And it is by competing $T$ might block the spread of infection.

Concentrating on peptide T, Pert's laboratory has now extended the initial observations to different cells, further refined the peptide structure and devised a more sophisticated test of peptide binding. In the meantime, Dr Lennart Wetterberg of the Karolinska Institute in Stockholm has given the peptide to four AIDS patients and observed some suggestive return towards normality of the nuclear magnetic resonance images of their brains. Rather than yet claim that the peptide is responsible, he will await the outcome of a controlled trial involving 36 patients that has just begun in Sweden.

US trials will be set up by Dr Frederick Goodwin, principal investigator in the submission approved by FDA. It remains to be seen whether the data of Haseltine, which he says are supported by others in US, UK, Swedish, Australian and Dutch laboratories, will give pause for thought. But with the great pressures to find new drugs for AIDS, the FDA seems unlikely to back away from a drug that at worst is likely to be harmless.
Peter Newmark with the virus for the receptor that peptide
Chernobyl cancellation London

ThE chairman of the USSR State Committee for Atomic Energy, Andronik Petrosyants, has announced that the construction of two more reactors (Nos 5 and 6) at the Chernobyl site has been cancelled. According to the Moscow weekly Literaturnaya Gazeta, the decision was taken "by a large majority of votes" at a conference in Kiev, attended by about 60 scientists. In March 1986, just a month before the disaster, the Kiev weekly Literaturna Ukrayina had drawn attention to sloppy workmanship and corner-cutting at the No. 5 site. Nevertheless, shortly after the accident, it was announced that construction work would resume shortly and that reactor No. 5 could become operational in autumn 1988.

V.R.

\section{Sizewell go-ahead}

\section{London}

BRITAIN's first nuclear power station using a pressurized water reactor (PWR) at Sizewell has been given the go-ahead by the Nuclear Installations Inspectorate (NII), three months after government approval.

The Central Electricity Generating Board plans to start the first stage of construction, a deep barrier wall to prevent seawater intrusion costing $£ 8$ million, at the end of the month. Safety requirements will also be monitored at the next stages of construction, according to the NII.

Critics of the PWR question the timing of the licence, at the height of Britain's general election campaign. All the opposition parties say said they would abandon the Sizewell B PWR power station K.J. - A long-term study of the health effects of radiation exposures from the Chernobyl accident will be carried out by Soviet scientists, a meeting of the World Health Organisation and the International Atomic Energy Agency has been told.

Soviet authorities say they plan to monitor over the next $\mathbf{4 0}$ or 50 years the health of 135,000 people evacuated from the most heavily contaminated area. "Unlimited funds" have been assigned to the study.

The research is considered internationally important in establishing whether there is a threshold of radiation dosage for the appearance of effects.

\section{Argentina's nuclear energy London}

Argentina's National Commission for Atomic Energy (CNEA) has a new chairperson, Mrs Emma Victoria Perez Ferreyra. Her predecessor, Alberto Constantini, resigned in April, saying that he could no longer continue under the current financial constraints on CNEA. During the interregnum, a 15-day strike of CNEA personnel for increased salary and pension rates brought virtually all projects to a standstill. 